LETTER TO JMG

\title{
The oestrogen receptor $\alpha$ gene is linked and/or associated with age of menarche in different ethnic groups
}

\author{
J-R Long, H Xu, L-J Zhao, P-Y Liu, H Shen, Y-J Liu, D-H Xiong, P Xiao, Y-Z Liu, V Dvornyk, J-L Li, \\ R R Recker, H-W Deng
}

$\mathrm{T}$ he first menstrual period, menarche, is one of the most significant milestones in a woman's life. The age at menarche is an important anthropological variable which may influence the overall duration of tissue oestrogen exposure and then affect health in later life. Early menarche is a well established risk factor for the development of breast cancer ${ }^{1}$ and endometrial cancer. ${ }^{2}$ Women with a menarcheal age of 10 or 11 years have a 2.2 times greater risk of breast cancer than women who had their first menstrual period at the age of 12 years or more. ${ }^{1}$ Those with a menarcheal age of 17 years or more have a $45 \%$ lower risk of endometrial cancer. ${ }^{2}$ Early age at menarche is also associated with a risk for obesity ${ }^{3}$ and depression in later life. ${ }^{4}$ On the other hand, late menarche is associated with lower bone mass and an increased risk of osteoporotic fractures ${ }^{5}$ and Alzheimer's disease. ${ }^{6}$ Therefore an understanding of potential factors responsible for the age of menarche is of considerable interest and may shed light on our understanding of these diseases.

Age at menarche is a complex trait that is determined by multiple environmental factors, including nutrition, exercise, socioeconomic conditions, psychosocial stimuli, childhood experience, general health, ${ }^{6-10}$ and genetic factors. Twin studies have shown that $53-74 \%$ of the variation in menarcheal age is attributed to genetic effects. ${ }^{11}$ Family history is a strong predictor of early menarche, ${ }^{10}$ and there are highly significant correlations between menarcheal ages of mothers and daughters. ${ }^{7}$ However, the specific genetic determinants of menarcheal age remain unclear. Oestrogen receptor $\alpha$ (ESRl) plays a distinct physiological role in mediating the specific effects of oestrogen ${ }^{12}$; thus the ESRl gene may serve as a candidate gene for age at menarche. A preliminary study in Greek adolescent girls ${ }^{13}$ suggested an association between the ESRl gene and age at menarche. However, such an association was not observed in Japanese women ${ }^{14}$ or Dutch women. ${ }^{15} 16$

To determine the importance of the ESRl gene for the onset of menstruation, we conducted a linkage study on a genomic region of $\sim 80 \mathrm{cM}$ centring on the ESRl gene. We then carried out an association study in an independent white population. Association was also tested in a sample of Chinese females.

\section{METHODS \\ Subjects}

In the linkage study, the sample was composed of 939 female offspring from 304 white families. There were two to eight female offspring in each family, giving a total of 1140 sister pairs. The available parents of the families were included for genotyping to improve the accuracy of the IBD (identity by descent) inference and thus maximise the power of linkage analysis. In the association study, 397 unrelated white females were included. From our previous epidemiological study, ${ }^{17}$ menarcheal age was available in 390 unrelated

\section{Key points}

- Menarche is a significant milestone. The age of menarche is an important anthropological variable which may influence the total duration of tissue oestrogen exposure and then affect health in later life. The oestrogen receptor $\alpha$ (ESRI) gene plays an important role in mediating oestrogen signalling.

- Relatively little is known about the impact of the ESR1 gene on the age of menarche. To test the importance of this gene on the onset of menstruation, a linkage mapping study was carried out on a genomic region of $\sim 80 \mathrm{cM}$ centring on the ESRI gene on chromosome 6 in 1140 white sister pairs.

- Linkage signal was obtained with a two point LOD score of 2.90 (empirical $p=0.001$ ) and a multipoint LOD score of 2.01 (empirical $p=0.003$ ). After Bonferroni correction for multiple testing, linkage signal remained with $p$ values of 0.01 and 0.03 for two point and multipoint analyses, respectively.

- Subsequently, in an independent sample of 397 unrelated white women, two single nucleotide polymorphisms in the ESR1 gene, rs3778082 and rs2228480, were associated with menarcheal age with $p$ values of 0.03 for both markers.

- In a sample of 390 unrelated Chinese females, potential interaction between the ESRI and the VDR (vitamin D receptor) genes was observed $(p=0.03)$, which indirectly suggested the potential effect of the ESRI gene on the age of menarche.

- According to the results of the linkage and association studies, the ESRI gene may have an effect on menarcheal age.

Chinese females. These were also used to test the relation between the ESRl gene and age at menarche.

The studies were approved by the Creighton University institutional review board or the Research Administration Department of Hunan Normal University. All the study subjects signed informed consent documents before entering the project. The age of menarche for each female subject was recorded by nurse administered questionnaires.

\section{Genotyping}

DNA was extracted from whole blood employing a Puregene DNA isolation kit (Gentra Systems, Minneapolis, Minnesota,

Abbreviations: ESR, oestrogen receptor; HWE, Hardy-Weinberg equilibrium; IBD, identity by descent; SNP, single nucleotide polymorphism 


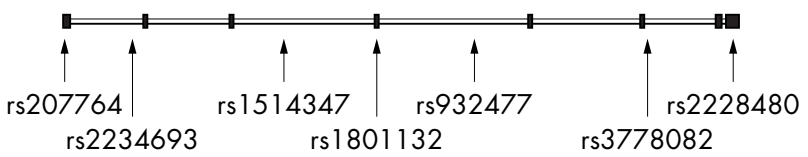

B

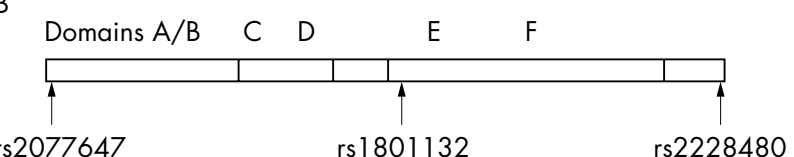

Figure 1 (A) Sketch of positions of the single nucleotide polymorphisms studied in the ESR1 gene. Exons are depicted as filled boxes and introns as double lines. (B) Location of the three coding SNPs in the six functional domains ( $A$ to $F$ ) of the ESR1 gene.

USA). In the white linkage study, 10 microsatellite markersD6S287, D6S262，D6S292， D6S308，D6S441， D6S1581, D6S264, D6S1697, D6S446, and D6S281-were genotyped by using 3700 DNA analyser (Applied Biosystems, Foster City, California, USA). These markers were scattered on a region of $\sim 80 \mathrm{cM}$ centred on the ESRl gene. The genotyping procedure for microsatellites has been described previously. ${ }^{18}$ PedCheck ${ }^{19}$ was employed to check the confirmation of Mendelian inheritance at all marker loci and to verify the sibling relations. In the white association study, seven SNPs were chosen based on their physical location within the ESR 1 gene (fig 1A). Among these, three were located in the coding region (rs2077647 (10 Ser), rs1801132 (325 Pro), and rs2228480 (594 Thr)). Figure 1B shows their position in the functional domains of the ESRl gene. The genotyping procedure for each single nucleotide polymorphism (SNP) was similar, ${ }^{20}$ involving a polymerase chain reaction (PCR) and invader assay reaction (Third Wave Technology, Madison, Wisconsin, USA). In the Chinese sample, two SNPs within the ESRl gene (XbaI and PvuII) and one in the VDR gene (ApaI) were genotyped by polymerase chain reaction-restriction fragment length polymorphism (PCRRFLP).

\section{Statistical analyses Linkage study}

A variance component linkage analysis for quantitative trait was carried out by employing the program SOLAR (http:// www.sfbr.org/solar/). Two point and multipoint linkage analyses were conducted by using the maximum likelihood method, based on specifying the expected genetic covariance

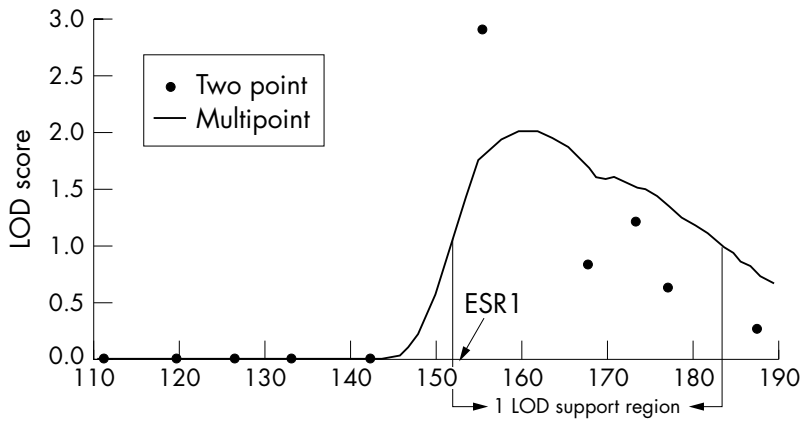

Chromosome region from pter of chromosome 6 (cM)

Figure 2 Linkage analysis profile for a region of $\sim 80 \mathrm{cM}$ centred on the ESR 1 gene. The $x$ axis shows the distance in centimorgans from pter of chromosome 6; the $y$ axis shows the LOD score. Black dots are for two point analysis and the line is for the multipoint analysis.

between sister pairs as a function of the IBD at a given marker locus. Pointwise empirical probability ( $p$ values) were estimated using the procedure "lodadj" implemented in SOLAR. This procedure samples the null distribution (the distribution of LOD (log of odds) scores obtained under the no linkage hypothesis), so that a sorted array of LOD scores is obtained; the proportion of LOD scores greater than the observed LOD score is the latter's empirical $p$ value. In all, 10000 replicates were generated.

\section{Association study in whites}

The $\chi^{2}$ test was employed to examine Hardy-Weinberg equilibrium (HWE) at the seven SNPs. The relation between these SNPs and the age at menarche was explored using analysis of variance (ANOVA). The frequencies of the minor allele homozygote for SNPs rs1514347, rs1801132, rs932477, rs 3778082 , and rs 2228480 were low $(4.0 \%, 4.1 \%, 0.3 \%, 1.3 \%$, and $3.3 \%$, respectively). Thus during the data analysis for these five SNPs, the subjects were divided into two groups, with and without the minor allele.

\section{Association study in Chinese}

The PvuII and XbaI polymorphisms are only 45 base pairs (bp) apart and they are in strong linkage disequilibrium ${ }^{17}$; thus the haplotypes based on the two SNPs were tested as genetic markers. For the VDR gene, subjects were divided into two groups, with and without the minor allele, owing to the low frequency of minor allele homozygosity (6.2\%). The potential interaction between the ESRI and the VDR genes was also tested. All the above statistical analyses were

Table 1 Information on the seven single nucleotide polymorphisms studied in the ESR 1 gene in white women

\begin{tabular}{llllll}
\hline SNP* & Polymorphism† & Location in gene & $\begin{array}{l}\text { Allele } \\
\text { frequency }\end{array}$ & $\begin{array}{l}\text { Genotype } \\
\text { frequency§ }\end{array}$ & p Valueq \\
\hline rs2077647 & T-C (10 Ser) & Exon 1 & 49.8 & 18.1 & $<0.01$ \\
rs2234693 (Pvull) & T-C & Intron 1 & 44.8 & 21.9 & 0.12 \\
rs1514347 & G-A & Intron 3 & 23.9 & 4.0 & 0.06 \\
rs1801132 & G-C (325 Pro) & Exon 4 & 20.3 & 4.1 & 0.95 \\
rs932477 & G-A & Intron 4 & 9.8 & 0.3 & 0.11 \\
rs3778082 & G-A & Intron 6 & 13.1 & 1.3 & 0.43 \\
rs2228480 & G-A (594 Thr) & Exon 8 & 19.5 & 3.3 & 0.50 \\
\hline
\end{tabular}

*SNP ID in the database dbSNP, www.ncbi.nlm.nih.gov/SNP.

†Bold faced letters are the minor alleles.

$\ddagger$ The allele frequencies are for minor alleles.

§Frequency of the homozygote at minor allele.

-Probability of the ? ${ }^{2}$ test for Hardy-Weinberg equilibrium

SNP, single nucleotide polymorphism. 
Table 2 Pairwise linkage disequilibrium $\left(D^{\prime}\right)$ between the seven single nucleotide polymorphisms studied in the ESR1 gene

\begin{tabular}{lrrrrrrrr}
\hline SNPs & rs2077647 & Pvull & \multicolumn{2}{c}{ rs1514347 } & rs1801132 & rs932477 & rs3778082 & rs2228480 \\
\hline rs2077647 & & & 0.511 & 0.166 & 0.020 & 0.143 & 0.168 & 0.114 \\
Pvu II & 34258 & & & 0.159 & 0.270 & 0.088 & $0.131^{*}$ & 0.103 \\
rs1514347 & 100368 & 66110 & & 0.634 & 0.576 & 0.313 & 0.116 \\
rs1801132 & 136445 & 102187 & 36077 & & 0.676 & 0.370 & 0.253 \\
rs932477 & 175519 & 141261 & 75151 & 39074 & & 0.675 & 0.360 \\
rs3778082 & 258587 & 224329 & 158219 & 122142 & 83068 & & 0.028 \\
rs2228480 & 291018 & 256760 & 190650 & 154573 & 115499 & 32431 & \\
\hline
\end{tabular}

Upper right triangle, $\mathrm{D}^{\prime}$; lower left triangle, physical distance in the unit (base pairs).

conducted employing the program SPSS V. 10 (SPSS Inc, Chicago, Illinois, USA).

\section{RESULTS}

\section{Descriptive characteristics}

In the linkage study, the sisters were on average 45.3 years old and their mean age at menarche was 13.1 years. The skewness and kurtosis values of age at menarche were fairly minor -0.45 and 0.50 , respectively. Generally, the variance component analyses implemented in SOLAR are robust to deviation of normality. ${ }^{21}$ However, kurtosis or skewness values greater than 2 may inflate the type I error rate..$^{22}$ Hence our data are amenable to linkage analyses using the variance component method. In the white association study, the subjects were on average 60.5 years old. Their mean menarcheal age was 12.9 years, which was not different from the women in the linkage study $(\mathrm{p}>0.05)$. The Chinese women were on average 31.0 years old. Their age of menarche ranged from 10.0 to 17.0 , with a mean value of 13.6 years, which was significantly later than in the two white populations.

\section{Linkage study}

Linkage signal was achieved at the marker D6S1581, about $155 \mathrm{cM}$ from the tip of the short arm of chromosome 6, with a two point LOD score of 2.90 (fig 2). Ten thousand simulations revealed an empirical pointwise $\mathrm{p}$ value of 0.001 for this linkage peak. A multipoint LOD score of 2.01 (empirical $\mathrm{p}$ value of 0.003 ) was obtained at $6 \mathrm{q} 25.3$, which is close to the location of the ESRl gene, 6q25.1. The marker closest to the linkage peak, about $161 \mathrm{cM}$ from the $\mathrm{p}$ terminal of chromosome 6, was still the marker D6S1581. The 1-LOD support interval around the linkage peak was mapped to a $32 \mathrm{cM}$ region. After adjusting for multiple testing using the most conservative method (Bonferroni correction ${ }^{23}$ ), the linkage signal remained, with $\mathrm{p}$ values of 0.01 and 0.03 for two point and multipoint analyses, respectively.

\section{Association study in white women}

The minor allele frequencies for the seven SNPs (rs2077647, PvulI, rs1514347, rs1801132, rs932477, rs3778082, and rs 2228480 ) were $49.8 \%, 44.8 \%, 23.9 \%, 20.3 \%, 9.8 \%, 13.1 \%$, and $19.5 \%$, respectively (table 1 ). The $\chi^{2}$ tests showed that except for rs2077647 all were in HWE ( $>>0.05)$.

The physical distance among the SNP pairs ranged from 32 to $291 \mathrm{~kb}$ with an average of $133 \mathrm{~kb}$. Pairwise linkage disequilibrium between the seven SNPs, calculated by $\mathrm{D}^{\prime}$, ranged from 0.020 to 0.676 , with a mean value of 0.280 (table 2). If $\mathrm{D}^{\prime}=0.7$ was used as an arbitrary limit for useful linkage disequilibrium in association studies, ${ }^{24}$ none of the pairs would fall below this threshold. Thus the haplotype analysis was not pursued.

Association with the age at menarche was observed at two SNPs, rs3778082 and rs2228480 (table 3). For the marker rs3778082, menarche occurred about four months later in women with the minor allele $A$ than in women without it, at (mean $(\mathrm{SE})) 13.2(0.2)$ years $v 12.9(0.1)$ years $(\mathrm{p}=0.03)$. For the marker rs2228480, minor allele $A$ carriers had an onset of menarche of about five months earlier than the non-carriers, at $12.7(0.1) v 13.1(0.1)$ years $(p=0.03)$. For the other five SNPs, we did not find any association $(\mathrm{p}>0.05)$.

\section{Association study in Chinese women}

The minor allele frequencies for XbaI, PvuII, and ApaI in the Chinese sample were $22.4 \%, 37.1 \%$, and $27.4 \%$, respectively. All these three loci were in HWE $(\mathrm{p}>0.05)$. We did not find any direct association with age of menarche for the three loci in the Chinese sample; however, a potential interaction between the ESRl and the VDR genes was observed (table 4). With genotype aa at the ApaI locus of the VDR gene, subjects carrying haplotype $P X$ (reconstructed by XbaI and PvuII) at

Table 3 Association analyses for the seven single nucleotide polymorphisms with the age of menarche in white women

\begin{tabular}{|c|c|c|c|c|c|c|c|}
\hline SNP & Genotype 11 & $n$ & Genotype 12 & $n$ & Genotype 22 & $\mathbf{n}$ & p Value \\
\hline rs2077647 & $13.1(0.2)$ & 72 & $12.9(0.1)$ & 251 & $12.8(0.2)$ & 74 & 0.45 \\
\hline \multirow[t]{2}{*}{ Pvull } & $12.9(0.2)$ & 87 & $13.0(0.1)$ & 180 & $12.9(0.1)$ & 128 & 0.58 \\
\hline & $\begin{array}{l}\text { Genotypes } 11 \\
\text { and } 12\end{array}$ & $\mathbf{n}$ & & & Genotype 22 & $\mathbf{n}$ & p Value \\
\hline rs1514347 & $12.9(0.1)$ & 174 & & & $12.9(0.1)$ & 223 & 0.94 \\
\hline rs1801132 & $12.9(0.1)$ & 144 & & & $13.0(0.1)$ & 251 & 0.87 \\
\hline rs932477 & $13.1(0.2)$ & 77 & & & $12.9(0.1)$ & 320 & 0.36 \\
\hline rs3778082 & $13.2(0.2)$ & 99 & & & $12.9(0.1)$ & 298 & 0.03 \\
\hline rs2228480 & $12.7(0.1)$ & 142 & & & $13.1(0.1)$ & 255 & 0.03 \\
\hline
\end{tabular}




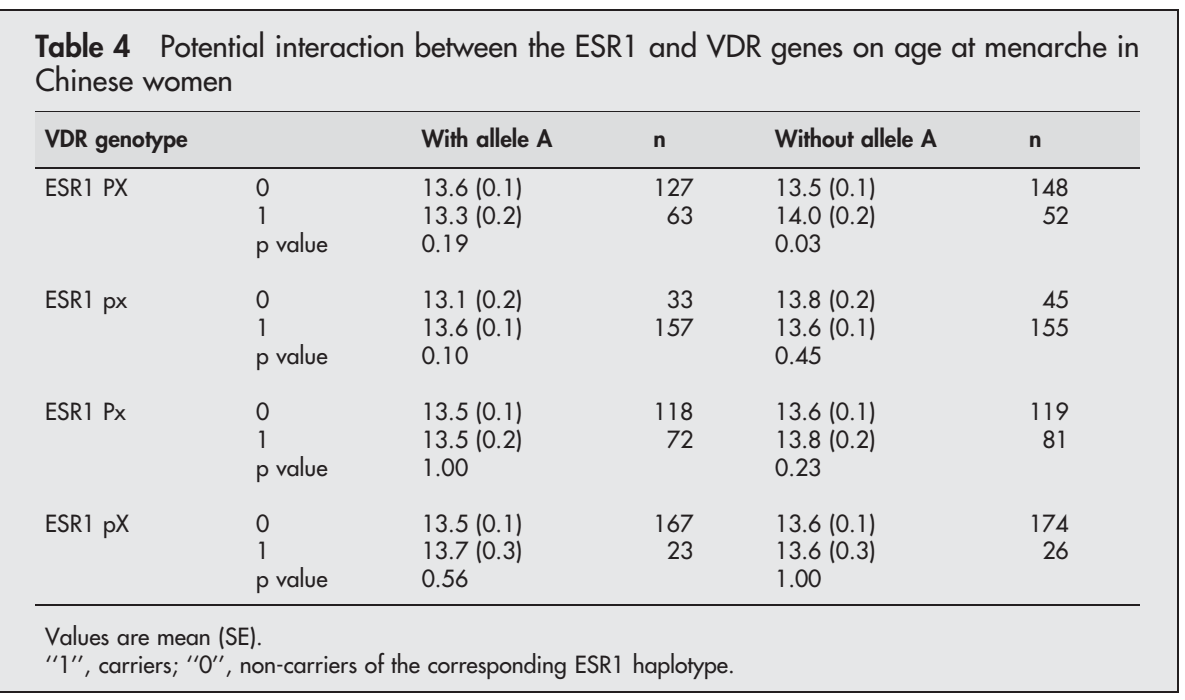

the ESRl gene had menarche about six months later $(\mathrm{n}=52$; $14.0(0.2)$ years, mean (SE)) than in the non-carriers $(\mathrm{n}=148 ; 13.5(0.1)$ years, $\mathrm{p}=0.03)$. This suggests a potential effect of the ESRl gene on the onset of menstruation. However, after correction for multiple testing, this interaction effect between the two genes did not reach statistical significance.

\section{DISCUSSION}

To test the importance of the ESRl gene on the age of menarche, we first undertook a linkage study on a genomic region of $\sim 80 \mathrm{cM}$ centred on the ESRI gene. Linkage signal was achieved with a two point LOD score of 2.90 and a multipoint LOD score of 2.01. Subsequently, association was observed at two SNPs in the ESRl gene, rs3778082 and rs2228480, in an independent unrelated white population.

It is not unexpected to find the effects of the ESRl gene on variation in menarcheal age, considering its functional importance. Oestrogen signalling is largely mediated in the oestrogen receptors, including oestrogen receptor $\alpha .^{25}$ The onset of menstruation is initiated by an increased amplitude of oestrogen exposure of tissues. ${ }^{26}$ One can therefore assume that the ESRl gene has some effect on the onset of menstruation.

ESRl has been categorised into six functional domains, A to F (fig $1 \mathrm{~B}$ ), and the rs 2228480 lies in the $\mathrm{F}$ domain. The function of the $\mathrm{F}$ domain is not clearly understood. It is thought to play a role in distinguishing between receptor agonist and antagonist binding to the receptor molecule, ${ }^{27}$ which affects the metabolism of oestrogen. SNP rs2228480 is a silent polymorphism; however, it may be correlated with oestrogenic biological activity, because gene expression could be affected through a structural change in mRNA and this may lead to an alteration in processing or efficiency of translation. SNP rs2228480 has been associated with several major diseases where lifetime oestrogen exposure is a potentially important risk modifier. For example, Roodi et $a l^{28}$ found that the minor allele $A$ was associated with an increased risk of breast cancer because of early exposure to oestrogen. Our observed association of the allele $A$ with early menarche is in agreement with their results. SNP rs3778082, located in intron 6, was first reported in a Japanese population $^{29}$ and it has never been tested for any disease trait. It may act as a regulatory element in mediating transcription or stability of mRNA, and also as a protein binding site to affect the function of this gene. The possible association of the two SNPs may come from the linkage disequilibrium with a truly causative sequence variation elsewhere in the ESRl gene or even in another nearby gene. For the other five SNPs studied, no association was observed, partly because they may not be in linkage disequilibrium with the functional polymorphisms.

In our Chinese population, a potential interaction between the ESRl and the VDR genes was observed, which may indirectly suggest the potential effect of the ESRI gene. The mechanism for the interaction is unclear; however, from a physiological point of view, there are some plausible explanations. An oestrogen responsive promoter region has been characterised in the VDR gene, and the transcription of the VDR promoter is dependent on oestrogen receptor. ${ }^{30}$ On the other hand, vitamin D is an important factor in oestrogen biosynthesis, ${ }^{31}$ and may influence the balance between oestrogens and androgens. ${ }^{32}$ Vitamin D may act along the oestrogen response pathway, affecting the levels of oestrogen receptors as well as their function. ${ }^{33}$

Several issues arise in this study. First, the age at menarche was collected retrospectively from adults, which may increase the likelihood of error. It is a limitation that there is no objective criterion to define the phenotype for these women, such as Tanner's developmental stages. However, menarche is one of the most important milestones in a female's life. Retrospective recall is reasonably accurate. A recent study showed a correlation of 0.79 between the original age of menarche and the information recalled 30 years later. ${ }^{34}$ Second, menarcheal age is affected by living environmental factors. Such information was not recorded and not used as covariates to adjust the raw data. However, in the linkage study, we limited our subjects to sister pairs, who were likely to live in more similar environments than the other relative pairs, such as grandparent-grandchild and aunt-niece. In the association study, the subjects' age limits were similar and they may have had a similar living environment. Such subject ascertainment could improve the accuracy of the linkage and association results. Third, most people reported menarcheal age in years and months; however, some reported it as whole years, which will affect the accuracy of the result. Fourth, the data in the Chinese study came from another project. The marker set was not the same as in the white subjects. The SNPs XbaI and ApaI were not genotyped in the white sample, and the two SNPs with significant results in white subjectsrs3778082 and rs2228480-were not genotyped in the Chinese. It would be more interesting to genotype the same markers in the two ethnic groups. In addition, in the VDR gene, only one marker (ApaI) was studied. It would be interesting to genotype more markers in the VDR gene, such as BsmI and TaqI, in a larger sample to confirm the potential 
interaction effect between the ESRl gene and the VDR gene on the age at menarche.

To our knowledge, this is the first study to show the effects of the ESRl gene on the age at menarche based on both linkage and association studies in independent populations. For further exploration of the relation between the ESRI gene and the age of menarche, studies with a larger sample size and denser markers are required.

\section{ACKNOWLEDGEMENTS}

The investigators were partially supported by grants from Health Future Foundation, NIH, the State of Nebraska (LB595 and LB692), US Department of Energy, Chinese National Science Foundation, the Ministry of Education of PR China, Huo Ying Dong Education Foundation, and Hunan Normal University. The study also benefited from 211 State Key Research Fund to Xi'an Jiaotong University.

\section{Authors' affiliations}

J-R Long, L-J Zhao, P-Y Liu, H Shen, Y-J Liu, D-H Xiong, P Xiao, Y-Z Liv, V Dvornyk, R R Recker, H-W Deng, Osteoporosis Research Centre and Department of Biomedical Sciences, Creighton University, Omaha, Nebraska, USA

H-W Deng, The Key Laboratory of Biomedical Information Engineering of Ministry of Education and Institute of Molecular Genetics, Xi'an Jiaotong University, Xi'an, China

J-L Li, Center for Medical Informatics, School of Medicine, Yale University, New Haven, Connecticut, USA

H Xu, H-W Deng, Laboratory of Molecular and Statistical Genetics, College of Life Sciences, Hunan Normal University, Changsha, Hunan, China

Competing interests: none declared

Correspondence to: Dr Hong-Wen Deng, Osteoporosis Research Center, Creighton University, 601 N 30th St, Suite 6787, Omaha, Nebraska 68131, USA; deng@creighton.edu

Received 18 October 2004

Revised version received 27 January 2005

Accepted for publication 2 February 2005

\section{REFERENCES}

1 Peeters PH, Verbeek AL, Krol A, Matthyssen MM, de Waard F. Age at menarche and breast cancer risk in nulliparous women. Breast Cancer Res Treat 1995:33:55-61.

2 Xu WH, Xiang YB, Ruan ZX, Zheng W, Cheng JR, Dai Q, Gao YT, Shu XO Menstrual and reproductive factors and endometrial cancer risk: Results from a population-based case-control study in urban Shanghai. Int J Cancer 2004; 108:613-19.

3 Wasserman L, Flatt SW, Natarajan L, Laughlin G, Matusalem M, Faerber S, Rock CL, Barrett-Connor E, Pierce JP. Correlates of obesity in postmenopausal women with breast cancer: comparison of genetic, demographic, diseaserelated, life history and dietary factors. Int J Obes Relat Metab Disord 2004;28:49-56

4 Harlow BL, Cohen LS, Otto MW, Spiegelman D, Cramer DW. Early life menstrual characteristics and pregnancy experiences among women with and without major depression: the Harvard study of moods and cycles. J Affect Disord 2004:79: 167-76.

5 Ito M, Yamada M, Hayashi K, Ohki M, Uetani M, Nakamura T. Relation of early menarche to high bone mineral density. Calcif Tissue Int 1995; $57: 11-14$

6 Rees $\mathbf{M}$. The age of menarche. ORGYN 1995:2-4

7 Treloar SA, Martin NG. Age at menarche as a fitness trait: nonadditive genetic variance detected in a large twin sample. Am J Hum Genet 1990;47:137-48

8 Meyer JM, Eaves $\amalg$, Heath AC, Martin NG. Estimating genetic influences on the age-at-menarche: a survival analysis approach. Am J Med Genet 1991;39:148-54

9 Kaprio J, Rimpela A, Winter T, Viken RJ, Rimpela M, Rose RJ. Common genetic influences on BMl and age at menarche. Hum Biol 1995;67:739-53.

10 Chie WC, Liu YH, Chi J, Wu V, Chen A. Predictive factors for early menarche in Taiwan. J Formos Med Assoc 1997:96:446-50.
11 Sharma K. Genetic basis of human female pelvic morphology: a twin study. Am J Phys Anthropol 2002;1 17:327-33.

12 Pelletier G, El Alfy M. Immunocytochemical localization of estrogen receptors alpha and beta in the human reproductive organs. J Clin Endocrinol Metab 2000;85:4835-40.

13 Stavrou I, Zois C, loannidis JP, Tsatsoulis A. Association of polymorphisms of the oestrogen receptor alpha gene with the age of menarche. Hum Reprod 2002; 17:1101-5

14 Gorai I, Tanaka K, Inada M, Morinaga H, Uchiyama Y, Kikuchi R, Chaki O, Hirahara F. Estrogen-metabolizing gene polymorphisms, but not estrogen receptor-alpha gene polymorphisms, are associated with the onset of menarche in healthy postmenopausal Japanese women. J Clin Endocrinol Metab 2003;88:799-803.

15 Weel AE, Uitterlinden AG, Westendorp IC, Burger H, Schuit SC, Hofman A, Helmerhorst TJ, van Leeuwen JP, Pols HA. Estrogen receptor polymorphism predicts the onset of natural and surgical menopause. J Clin Endocrinol Metab 1999;84:3146-50.

16 Boot AM, Van Der Sluis IM, Keizer-Schrama SM, Van Meurs JB, Krenning EP, Pols HA, Uitterlinden AG. Estrogen receptor alpha gene polymorphisms and bone mineral density in healthy children and young adults. Calcif Tissue Int, 2004, Feb 17 [Epub ahead of print]

17 Qin YJ, Shen H, Huang QR, Zhao L, Zhou Q, Li MX, He JW, Mo XY, Lu JH, Recker RR, Deng HW. Estrogen receptor alpha gene polymorphisms and peak bone density in Chinese nuclear families. J Bone Miner Res 2003; 18:1028-35.

18 Shen $\mathrm{H}$, Zhang YY, Long JR, Xu FH, Liu YZ, Xiao P, Zhao U, Xiong DH, Liu YJ, Dvornyk V, Rocha-Sanchez S, Liu PY, Li JL, Conway T, Davies KM, Recker RR, Deng HW. A genomewide linkage scan for bone mineral density in an extended sample: evidence for linkage on 11 q23 and Xq27. J Med Genet 2004;41:743-51

19 O'Connell JR, Weeks DE. PedCheck: a program for identification of genotype incompatibilities in linkage analysis. Am J Hum Genet 1998;63:259-66.

20 Zhao L, Liu PY, Long JR, Lu Y, Xu FH, Zhang YY, Shen H, Xiao P, Elze L, Recker RR, Deng HW. Test of linkage and/or association between the estrogen receptor alpha gene with bone mineral density in Caucasian nuclear families. Bone 2004;35:395-402

21 Williams JT, Van Eerdewegh P, Almasy L, Blangero J. Joint multipoint linkage analysis of multivariate qualitative and quantitative traits. I. Likelihood formulation and simulation results. Am J Hum Genet 1999;65:1134-47.

22 Allison DB, Neale MC, Zannolli R, Schork NJ, Amos Cl, Blangero J. Testing the robustness of the likelihood-ratio test in a variance-component quantitative-trait loci-mapping procedure. Am J Hum Genet 1999:65:531-44.

23 Boehringer S, Epplen JT, Krawczak M. Genetic association studies of bronchial asthma - a need for Bonferroni correction? Hum Genet 2000:107:197.

24 Tiret L, Poirier O, Nicaud V, Barbaux S, Herrmann SM, Perret C, Raoux S, Francomme C, Lebard G, Tregouet D, Cambien F. Heterogeneity of linkage disequilibrium in human genes has implications for association studies of common diseases. Hum Mol Genet 2002;11:419-29.

25 Speirs V, Adams IP, Walton DS, Atkin SL. Identification of wild-type and exon 5 deletion variants of estrogen receptor beta in normal human mammary gland. J Clin Endocrinol Metab 2000;85:1601-5.

26 Stoll BA. Western diet, early puberty, and breast cancer risk. Breast Cancer Res Treat 1998:49:187-93.

27 Pavao M, Traish AM. Estrogen receptor antibodies: specificity and utility in detection, localization and analyses of estrogen receptor alpha and beta. Steroids $2001 ; 66: 1-16$

28 Roodi N, Bailey LR, Kao WY, Verrier CS, Yee CJ, Dupont WD, Parl FF. Estrogen receptor gene analysis in estrogen receptor-positive and receptornegative primary breast cancer. J Natl Cancer Inst 1995;87:446-51

29 Haga H, Yamada R, Ohnishi Y, Nakamura Y, Tanaka T. Gene-based SNP discovery as part of the Japanese Millennium Genome Project: identification of 190,562 genetic variations in the human genome. Single-nucleotide polymorphism. J Hum Genet 2002;47:605-10.

30 Wietzke JA, Welsh J. Phytoestrogen regulation of a Vitamin D3 receptor promoter and 1,25-dihydroxyvitamin D3 actions in human breast cancer cells. J Steroid Biochem Mol Biol 2003;84:149-57.

31 Salmen T, Heikkinen AM, Mahonen A, Kroger H, Komulainen M, Saarikoski S, Honkanen R, Maenpaa PH. The protective effect of hormone-replacement therapy on fracture risk is modulated by estrogen receptor alpha genotype in early postmenopausal women. J Bone Miner Res 2000;15:2479-86.

32 Willing M, Sowers M, Aron D, Clark MK, Burns T, Bunten C, Crutchfield M, $D^{\prime}$ Agostino $D$, Jannausch $M$. Bone mineral density and its change in white women: estrogen and vitamin $D$ receptor genotypes and their interaction. $J$ Bone Miner Res 1998;13:695-705.

33 Swami S, Krishnan AV, Feldman D. lalpha,25-Dihydroxyvitamin D3 downregulates estrogen receptor abundance and suppresses estrogen actions in MCF-7 human breast cancer cells. Clin Cancer Res 2000;6:3371-9.

34 Must A, Phillips SM, Naumova EN, Blum M, Harris S, Dawson-Hughes B, Rand WM. Recall of early menstrual history and menarcheal body size: after 30 years, how well do women remember? Am J Epidemiol 2002;155:672-9. 